\title{
Analisis Teknikal Menggunakan Indikator MACD dan RSI pada Saham JII
}

\author{
Noor Elma Monika ${ }^{1}$, Meina Wulansari Yusniar ${ }^{2}$ \\ ${ }^{12}$ Magister Manajemen, Fakultas Ekonomi dan Bisnis, Universitas Lambung Mangkurat \\ Email : elmamonika@gmail.com
}

\begin{abstract}
This study aims to determine the difference between the price suggested by the MACD indicator and the RSI indicator with the close price of the stock. This study also aims to determine the differences between the MACD indicator and the RSI indicator on JII stocks during 2016 s.d. 2018. This type of research are descriptive quantitative and comparative. The purposive sampling technique produced 6 stocks as research samples with code: ADRO, BSDE, KLBF, PTPP, SMRA, and WIKA. Data analysis techniques in this study used the ChartNexus Version 5 application to analyze daily stock prices with MACD and RSI indicators. The price signal from the indicator is then paired with the closest close price of the stock. The research hypothesis were tested using the Mann Whitney test which processed using the SPSS 23 program. The results showed that there was no difference between the prices of the MACD indicator and RSI indicator signals with the close price of the stocks, so that the buy and sell signals produced accurately and could be used in stock trading. The results also show that there are no differences between the 2 indicators of technical analysis, so it can be stated that on the same object and period, MACD and RSI indicators statistically produce the sake investment decisions (buy signals and sell signals).
\end{abstract}

Keywords: JII, Technical Analysis, MACD Indicator, RSI Indicator, Buy Signal and Sell Signal, Close Price

Abstrak

Penelitian ini bertujuan untuk mengetahui perbedaan antara harga yang disarankan oleh indikator MACD dan indikator RSI dengan close price terdekat saham. Penelitian ini juga bertujuan untuk mengetahui perbedaan antara indikator MACD dengan indikator RSI pada saham JII tahun 2016 s.d. 2018. Jenis penelitian ini adalah deskriptif kuantitatif dan komparatif. Teknik purposive sampling menghasilkan 6 saham sebagai sampel penelitian dengan kode: ADRO, BSDE, KLBF, PTPP, SMRA, dan WIKA. Teknik analisis data pada penelitian ini menggunakan aplikasi ChartNexus Versi 5 untuk menganalisis harga saham harian dengan indikator MACD dan RSI. Sinyal harga dari indikator kemudian dipasangkan dengan close price terdekat saham. Hipotesis penelitian diuji menggunakan uji beda Mann Whitney yang diolah dengan program SPSS 23. Hasil penelitian menunjukkan bahwa tidak terdapat perbedaan antara harga dari sinyal indikator MACD dan RSI dengan close price terdekat saham, sehingga sinyal beli dan sinyal jual yang dihasilkan akurat dan dapat digunakan dalam perdagangan saham. Hasil penelitian juga menunjukkan bahwa tidak terdapat perbedaan antara 2 indikator analisis teknikal, sehingga dapat dinyatakan bahwa pada obyek dan periode yang sama, indikator MACD dan RSI menghasilkan keputusan investasi (sinyal beli dan sinyal jual) yang sama secara statistik.

Kata Kunci : JII, Analisis Teknikal, Indikator MACD, Indikator RSI, Sinyal Beli dan Sinyal Jual, Close Price

(C) 2020 Jurnal Riset Inspirasi Manajemen dan Kewirausahaan

\section{PENDAHULUAN}

Investasi syariah merupakan kegiatan penanaman modal pada instrumen investasi selama periode tertentu menggunakan sistem syariah. Tujuan dan niat investasi tidak boleh bertentangan dengan prinsip-prinsip syariah. Dasar investasi syariah adalah boleh selama belum ada dalil yang melarangnya. Investasi syariah ditunjukkan untuk usaha yang sesuai dengan syariat Islam serta bebas dari hal yang dilarang agama seperti riba (bunga), gharar (ketidakpastian), masyir (judi), tadlis (penipuan), darar (kerusakan/ kemudharatan) dan tidak mengandung maksiat (Pardiansyah, 2017: 350-351).

Investasi memerlukan alat bantu dalam pelaksanaannya. Kesalahan dalam pengambilan keputusan investasi akan menimbulkan kerugian bagi investor, oleh karena itu analisis saham dapat digunakan untuk mengurangi risiko yang ada pada 
investasi saham. Analisis teknikal digunakan untuk membantu proses analisis suatu saham dengan mudah dan cepat. Salah satu indikator yang mudah dan sering digunakan adalah indikator MACD yang dikenalkan oleh Gerald Appel pada tahun 1970-an dan indikator RSI (Relative Strength Index) oleh oleh J. Welles Wilder pada tahun 1978.

Keakuratan analisis teknikal pada penelitian terdahulu diketahui melalui perbandingan close price terdekat saham dengan harga dari sinyal indikator yang digunakan. Sinyal indikator dikatakan akurat jika sama dengan close price terdekat dengan pengujian statistik. Penelitian tentang analisis teknikal dengan indikator MACD dan RSI dalam perdagangan saham telah beberapa kali diteliti sebelumnya. Sebagian besar penelitian menyatakan penggunaan indikator MACD dan RSI menguntungkan, namun terdapat penelitian yang menyatakan indikator tersebut tidak menguntungkan.

Penelitian yang mendukung penggunaan indikator MACD dan RSI antara lain: Asthri, Topowijono, \& Sulasmiyati (2016) yang melakukan penelitian tentang analisis keputusan membeli dan menjual saham menggunakan indikator MACD pada perusahaan sektor makanan dan minuman di BEI; Raditya, Tarno, \& Wuryandari (2013) tentang penentuan tren harga saham menggunakan indikator MACD pada 6 anggota LQ45; Kodrat \& Indonanjaya (2010) dilakukan dengan indikator Relative Strength Index (RSI), Stochastic Oscillator (SO) dan Moving Average Converge Divergence (MACD) terhadap saham BMRI; Pandya (2013) yang menggunakan analisis teknikal (line chart, column chart, stock chart, EMA, MACD, RSI dan ROC) pada saham sektor Teknologi Informasi di India; Chong, $\mathrm{Ng} \&$ Liew (2014) di bursa efek OECD dan bursa negara berkembang tentang MACD dan RSI juga menunjukkan bahwa kedua indikator ini dapat digunakan dalam perdagangan saham.

Penelitian yang menyatakan indikator MACD dan RSI tidak menguntungkan dikemukakan oleh Pramono et al. (2013). Penelitian ini menggunakan indikator MACD, SO, RSI, buy and hold di sektor perbankan indeks LQ45. Penelitian dari Nor (2014) di bursa saham Australia juga menyatakan bahwa indikator MACD umumnya berkinerja buruk, meskipun RSI menunjukkan beberapa potensi keuntungan.

Analisis teknikal saat ini merupakan salah satu topik yang paling menarik dan menantang untuk dibahas pada ilmu keuangan. Indikator analisis teknikal merupakan metode yang paling sering digunakan investor untuk mengambil keputusan (Ghobadi, 2014:334). Penelitian analisis teknikal saat ini masih sangat sulit ditemukan, meskipun dalam praktiknya investor lebih sering menggunakan analisis teknikal untuk berinvestasi di pasar modal. Sangat disayangkan jika praktisi pasar modal tidak didukung oleh penelitian ilmiah dari para akademisi (Kodrat \& Indonanjaya, 2010:2).

Berdasarkan hasil penelitian terdahulu dan argumen yang ada, peneliti ingin menguji kembali apakah penggunaan analisis teknikal menggunakan indikator MACD dan RSI dapat dijadikan acuan dalam pengambilan keputusan investasi. Indikator MACD dan RSI pada penelitian dipilih karena telah memiliki standar perhitungan yang telah ditentukan. Menurut Raditya, Tarno, \& Wuryandari (2013:249), dari berbagai jenis analisis teknikal, indikator MACD merupakan indikator yang paling populer digunakan untuk alat analisis karena mudah digunakan pada semua jenis saham, sedangkan menurut Wira (2014:112), pada dasarnya penggunaan indikator RSI sangat mudah dimana investor hanya perlu melihat batas atas $70 \%$ dan bawah $30 \%$ untuk mengambil keputusan investasi.

Penelitian ini berbeda dari penelitian sebelumnya yang hanya membandingkan harga dari sinyal indikator dengan close price terdekat saham. Penelitian ini membandingkan indikator MACD dan RSI dengan close price serta membandingkan indikator MACD dengan indikator RSI melalui uji statistik. Penelitian terdahulu terkait analisis teknikal sebagian besar hanya memberikan analisis deskriptif dan tidak menggunakan uji statistik untuk pengambilan kesimpulan. Penelitian ini memiliki periode analisis yang lebih lama dibandingkan dengan penelitan sebelumnya yang menggunakan uji beda (Monika (2017); Raditya, Tarno, \& Wuryandari (2013); Asthri, Topowijono, \& Sulasmiyati (2016)) serta memiliki 2 indikator sebagai alat analisisnya. Penggunaan 2 indikator pada penelitian ini bertujuan sebagai pengembangan dari penelitian peneliti terdahulu di tahun 2017.

Objek pada penelitian ini adalah saham JII yang terdaftar di BEI tahun 2016 s.d. 2018. Sektor ini dipilih karena tingginya minat masyarakat dalam kegiatan investasi syariah di BEI. Saham JII sudah disaring dengan beberapa syarat seperti kapitalisasi dan likuidasi saham yang baik sehingga dapat langsung dianalisis. Aktifnya perdagangan suatu saham akan memudahkan proses analisis harga karena analisis teknikal menggunakan data historis harga saham. 


\section{KAJIAN LITERATUR}

\section{Investasi Syariah}

Investasi syariah terbagi menjadi dua jenis yaitu investasi aktiva riil dan aktiva finansial. Contoh investasi syariah dalam bentuk aktiva riil diantaranya yaitu investasi properti syariah dan emas syariah, sedangkan contoh investasi syariah aktiva finansial yaitu saham syariah, reksadana syariah, sukuk, deposito syariah, dan lain sebagainya (Putri, Bramanti, \& Hakim, 2017:134).

Pertimbangan investor syariah dalam membeli produk investasi yaitu dengan mematuhi syariat agama serta menghindari adanya transaksi margin trading atau short selling yang menggunakan dana sekuritas untuk membiayai kepentingan pribadi investor (Yustati, 2017:108-109).

\section{Pasar Modal}

Menurut Hanafi (2016:63), pasar modal adalah pasar yang melakukan transaksi jual beli instrumen keuangan dengan jangka waktu yang panjang. Pasar modal beroperasi secara teroganisir yang didalamnya terdapat aktivitas perdagangan surat berharga. Contoh instrumen keuangan jangka panjang yaitu: obligasi, saham, option, right issue dan warrant yang diterbitkan oleh pemerintah atau swasta dengan menggunakan perantara, underwriter dan komisioner.

Fungsi pasar modal adalah mempertemukan pihak yang memiliki kelebihan dana dengan pihak yang memerlukan dana. Pasar modal menjadi sarana investasi pada aset keuangan. Saham adalah salah satu surat berharga yang paling sering diperjualbelikan karena menawarkan tingkat keuntungan yang menarik (Asthri, Topowijono \& Sulasmiyati, 2016:42). Tempat terjadinya perdagangan sekuritas atau pasar modal secara fisik disebut bursa efek. Bursa efek di Indonesia terbentuk pada tahun 2007 dengan nama Bursa Efek Indonesia.

\section{Saham}

Saham merupakan salah satu bagian dari investasi dalam Islam. Saham adalah surat berharga sebagai tanda bukti kepemilikan modal investor atas bagian dari perusahaan tersebut. Konsep kepemilikan modal syariah yaitu dengan membagi hasil dari usaha perusahaan tersebut serta tidak bertentangan dengan prinsip syariah (Pardiansyah, 2017:361).

Investor yang membeli saham akan mendapatkan keuntungan sesuai dengan jumlah saham yang dimilikinya. Investor dapat melakukan jual beli saham setiap hari perdagangan sesuai dengan perubahan harga di pasar modal (Asthri, Topowijono, \& Sulasmiyati, 2016:43). Saham memiliki sifat high risk high return yang artinya investor bisa mendapatkan keuntungan yang tinggi namun dengan risiko yang tinggi pula (Pramono et al., 2013:273).

\section{Jakarta Islamic Index (JII)}

Jakarta Islamic Index (JII) merupakan indeks saham syariah yang diluncurkan pertama kali pada tanggal 3 juli 2000. JII merupakan indeks rata-rata harga saham syariah di BEI yang berawal dari kerjasama antara Bursa Efek Jakarta (sekarang BEI) dengan PT. Danareksa Invesment Management (PT DIM). JII terdiri dari 30 saham syariah yang dipilih 2 kali dalam setahun yaitu pada bulan Mei dan November. JII ditentukan dengan melakukan seleksi terhadap seluruh saham syariah di BEI. Syarat dan kriteria pemilihan saham JII dijelaskan pada situs BEI diengan alamat $\underline{\text { www.idx.co.id }}$

\section{SOTS (Shariah Online Trading System)}

Investor syariah yang ingin melakukan investasi di pasar modal dapat menggunakan sistem perdagangan saham syariah online yang dikeluarkan oleh sekuritas terdaftar. BEI dalam situsnya www.idx.go.id mendefinisikan Shariah Online Trading System (SOTS) sebagai sistem perdagangan saham yang transaksinya berdasar pada prinsip syariah di pasar modal. SOTS disertifikasi oleh DSN MUI (Dewan Syariah Nasional Majelis Ulama Indonesia) No. 80 tahun 2011. SOTS dibentuk dengan tujuan memfasilitasi investor syariah dalam melakukan perdagangan saham di BEI.

\section{Analisis Teknikal}

Menurut Filbert \& j1d, (2014:21), analisis teknikal merupakan analisis yang fokus pada pergerakan harga dan banyaknya transaksi sebuah saham. Investor menggunakan beberapa cara analisis untuk menentukan titik jual dan beli. Masing-masing analisis teknikal memiliki gambaran yang berbeda dalam penentuan perdagangan di bursa. Mengetahui karakter dari setiap saham merupakan strategi terbaik untuk menghasilkan informasi yang lebih akurat.

\section{Indikator MACD}

Menurut Wira (2014:107), Moving Average Convergence Divergence (MACD) adalah indikator yang berfungsi untuk menunjukkan trend yang sedang terjadi dalam perdagangan saham. Indikator ini mudah dibaca karena hanya menggunakan 2 garis yang saling berpotongan. Berikut adalah tampilan indikator MACD pada software ChartNexus versi 5: 


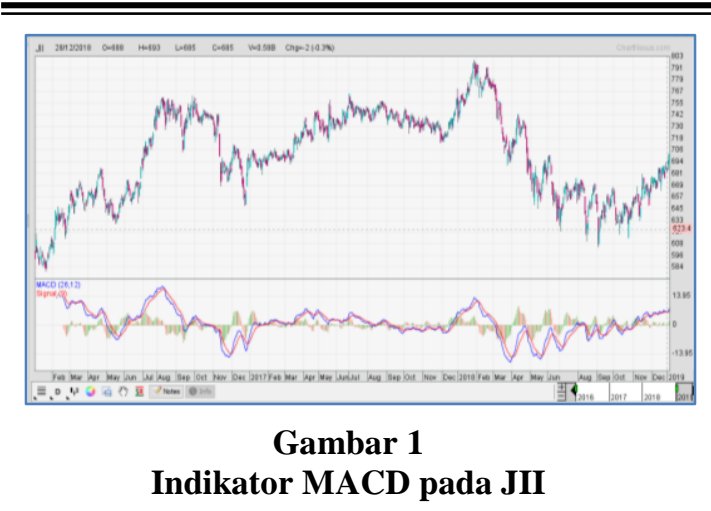

Menurut Wira (2014:108), indikator MACD terdiri dari 2 garis yaitu garis MACD (berwarna biru) dan garis sinyal (berwarna merah). Pada saat garis MACD dan garis sinyal bertemu atau saling berpotongan, maka pada saat itulah investor mengambil keputusan membeli atau menjual suatu saham. Sinyal beli terjadi ketika garis MACD memotong garis sinyal keatas (golden cross) dan sinyal jual terjadi ketika garis MACD memotong kebawah garis sinyal (death cross).

\section{Indikator RSI (Relative Strength Index)}

RSI dikembangkan oleh J. Welles Wilder pada tahun 1978. RSI merupakan suatu analisis yang mengukur kecepatan perubahan kenaikan dan penurunan dalam pergerakan harga saham. Indikator RSI dapat memberikan informasi apakah harga pasar sudah overbought atau oversold. Indikator RSI bernilai dari angka 1-100. Menurut Wira (2014:112), apabila posisi garis RSI berada diatas $70 \%$ maka saham sudah overbought (jenuh beli), sedangkan bila garis berada dibawah $30 \%$ maka saham sudah oversold (jenuh jual). Berikut adalah tampilan indikator RSI pada aplikasi ChartNexus versi 5:

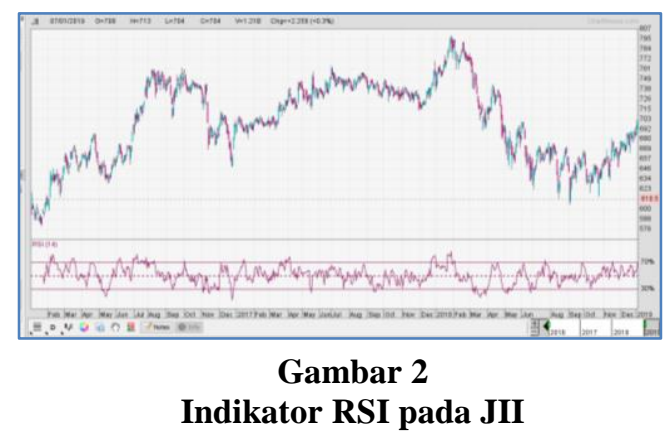

RSI hanya memiliki 1 garis yang naik turun mengikuti harga pasar dan bergerak pada rentang 1-100\%. Membaca arah indikator RSI sangat mudah, jika RSI bernilai sangat tinggi atau rendah (diatas 70 atau dibawah 30) berarti harga sudah jenuh dan kemungkinan besar akan berbalik arah. Posisi garis RSI yang berada diatas $70 \%$ menunjukkan sinyal untuk menjual, sedangkan sinyal untuk membeli terjadi jika garis berada dibawah 30\%, (Wira, 2014:112).

\section{Pasar Bullish dan Bearish}

Menurut Darmawan (dalam Aditama, 2016:29), istilah bullish dan bearish biasa digunakan oleh investor untuk menggambarkan situasi pasar yang sedang terjadi, baik pasar secara keseluruhan maupun pada suatu saham saja. Bullish berarti keadaan dimana pasar sedang dalam tren naik yang digambarkan sebagai optimisme investor, sebaliknya bearish merupakan keadaan dimana pasar dalam tren menurun dan investor dalam posisi pesimisme.

Kondisi pasar bullish dan bearish dapat dianalisis dengan indikator analisis teknikal. Kondisi pasar dapat juga dihitung dengan rumus cut off point untuk mengetahui keadaan indeks dari tahun ke tahun. Cut off point dihitung dengan metode arithmetic mean (simbol X bar). Menurut Tandelilin (dalam Aditama, 2016:37), arithmetic mean merupakan rumus untuk menghitung rata-rata yang dengan rumus:

$$
\begin{aligned}
& \overline{\mathrm{X}}=\frac{\Sigma \mathrm{X}}{n} \\
& \Sigma \mathrm{X}=\text { jumlah return selama suatu periode } \\
& \mathrm{N}=\text { jumlah periode }
\end{aligned}
$$

\section{Kerangka Pemikiran}

Kerangka berpikir dalam penelitian ini menjelaskan alur logika pemahaman dasar tentang garis besar proses penelitian yang akan dilakukan. Alur penelitian ini dapat digambarkan sebagai berikut:

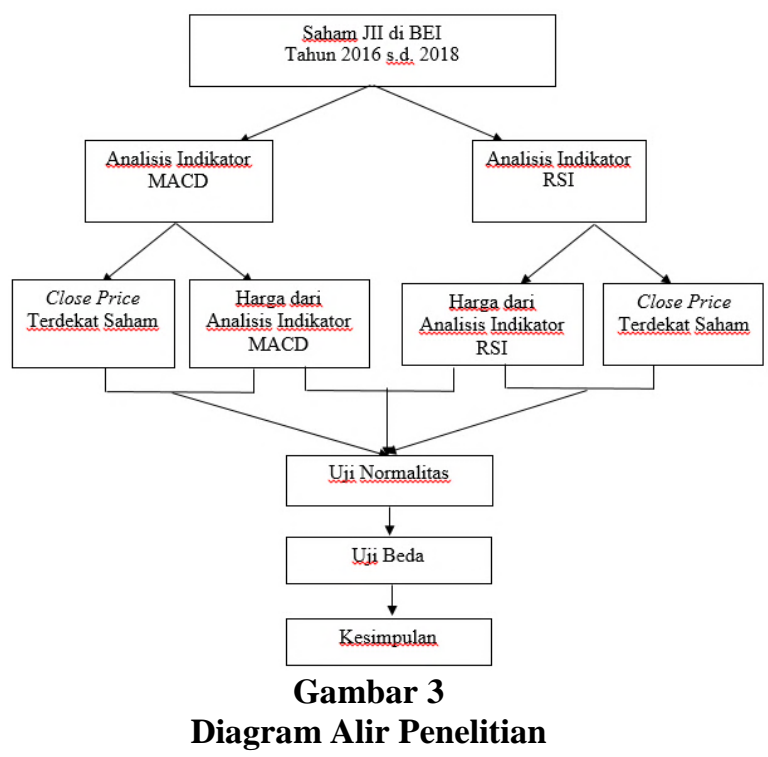


Hipotesis Penelitian

$\mathrm{H}_{01}$ :Tidak terdapat perbedaan antara harga dari indikator MACD dengan close price terdekat saham JII di BEI Tahun 2016 s.d. 2018.

$\mathrm{H}_{02}$ :Tidak terdapat perbedaan antara harga dari indikator RSI dengan close price terdekat saham JII di BEI Tahun 2016 s.d. 2018.

$\mathrm{H}_{03}$ :Tidak terdapat perbedaan antara harga dari indikator MACD dengan harga dari indikator RSI pada saham JII di BEI Tahun 2016 s.d. 2018.

\section{METODE PENELITIAN}

Jenis penelitian ini adalah deskriptif kuantitatif dan komparatif (perbandingan). Perbandingan harga yang dihasilkan indikator dengan close price terdekat dimaksudkan untuk mengetahui keakuratan analisis teknikal tersebut. Penelitian dilakukan di situs Bursa Efek Indonesia dan Yahoo Finance untuk melihat data harga serta pada aplikasi ChartNexus versi 5 untuk melihat data sinyal indikator MACD dan RSI. Populasi penelitian ini adalah saham Jakarta Islamic Index di BEI dari tahun 2016 s.d. 2018 dengan jumlah 43 saham. Sampel penelitian ini adalah 6 saham JII yang dipilih dari populasi berdasarkan teknik purposive sampling. 6 sampel penelitian ini adalah saham dengan kode: ADRO, BSDE, KLBF, PTPP, SMRA dan WIKA.

Tabel 1

Sampel Penelitian

\begin{tabular}{cclc}
\hline No & Kode & Nama Emiten & Harga (31 Des 2018) \\
\hline 1 & ADRO & Adaro Energy Tbk. & $\underline{\mathrm{Rp} 1.215}$ \\
2 & BSDE & $\underline{\text { Bumi Serpong Damai Tbk. }}$ & $\underline{\mathrm{Rp} 1.255}$ \\
3 & KLBF & Kalbe Farma Tbk. & $\underline{\mathrm{Rp} 1.520}$ \\
4 & PTPP & PP (Persero) Tbk. & $\underline{\mathrm{Rp} 1.805}$ \\
5 & SMRA & $\underline{\text { Summarecon Agung Tbk. }}$ & $\underline{\mathrm{Rp} 805}$ \\
6 & WIKA & $\underline{\text { Wijaya Karya (Persero) Tbk. }}$ & $\underline{\mathrm{Rp} 1.655}$ \\
\hline \multicolumn{3}{l}{ Sumber: www.idx.co.id, data diolah 2019 }
\end{tabular}

Langkah-langkah analisis data yang digunakan pada penelitian ini adalah sebagai berikut:

1. Melakukan pengumpulan data saham JII yang masuk pada tahun 2016 s.d. 2018 di BEI.

2. Melakukan analisis harga saham menggunakan indikator MACD dan RSI pada sampel penelitian dengan aplikasi ChartNexus versi 5.

3. Melakukan pendataan sinyal beli dan sinyal jual menggunakan indikator MACD dan RSI.

4. Pendataan close price terdekat dari situs yahoo finance untuk melihat harga dan tanggal saham.

5. Uji Normalitas data dengan Kolmogorov Smirnov menggunakan aplikasi SPSS 23.
6. Melakukan Uji beda menggunakan Mann Whitney.

7. Menarik kesimpulan.

\section{HASIL PENELITIAN DAN PEMBAHASAN}

Hasil pengujian $\mathrm{H}_{01}, \mathrm{H}_{02}$, dan $\mathrm{H}_{03}$ menunjukkan nilai Asymp. Sig. (2-tailed) normalitas data adalah sebesar 0,000; 0.000; dan 0,015 atau berada diatas bawah signifikansi $(0,05)$ yang berarti data tidak berdistribusi secara normal.

Tabel 1

ji Mann Whitney Indikator RSI dengan Close

\begin{tabular}{cc}
\hline Perbandingan & $\begin{array}{c}\text { Mann-Whitney } \\
\text { Asymp. Sig. (2-tailed) }\end{array}$ \\
\hline $\begin{array}{c}\text { Indikator MACD } \\
\text { dengan Close Price }\end{array}$ & 0,915 \\
\hline $\begin{array}{c}\text { Indikator RSI dengan } \\
\text { Close Price }\end{array}$ & 0,919 \\
\hline $\begin{array}{c}\text { Indikator MACD } \\
\text { dengan Indikator RSI }\end{array}$ & 0,715 \\
\hline
\end{tabular}

Hasil pada tabel 1 berada diatas tingkat signifikansi 0,05 yang berarti $\mathrm{H}_{01}$ dan $\mathrm{H}_{02}$ diterima, atau tidak terdapat perbedaan antara sinyal indikator dengan close price terdekat saham, sehingga indikator MACD dan RSI akurat untuk menentukan sinyal beli dan jual pada saham JII tahun 2016 s.d. 2018. Hasil uji $\mathrm{H}_{03}$ menunjukkan nilai Asymp. Sig. (2-tailed) sebesar 0,715 atau diatas signifikansi 0,05 yang menunjukkan bahwa pada obyek dan periode yang sama indikator MACD dan RSI menghasilkan keputusan investasi yang sama.

Nilai signifikansi uji beda indikator MACD dan RSI dengan close price lebih besar dari uji beda indikator MACD dengan indikator RSI $(0,915$ dan $0,919>0,715)$, sehingga dapat dikatakan bahwa tingkat kesamaan indikator MACD dan RSI dengan close price terdekat saham lebih tinggi dibandingkan tingkat kesamaan indikator MACD dengan indikator RSI. Tabel pasangan harga saham setiap sampel menunjukkan bahwa terdapat sedikit perbedaan antara harga dari indikator MACD dan RSI dengan close price terdekat saham, namun secara statistik dari hasil uji beda Mann Whitney dapat diketahui bahwa sinyal indikator dan close price terdekat saham tidak berbeda.

Hasil penelitian dengan uji beda ini mendukung penelitian dari Raditya, Tarno, \& Wuryandari (2013) yang menyatakan bahwa indikator MACD akurat digunakan pada 6 saham indeks LQ45 tahun 2012. Penelitian lain oleh 
https://ejurnal.stimi-bjim.ac.id/index.php/JRIMK

Asthri, Topowijono, \& Sulasmiyati (2016) menyatakan bahwa indikator MACD akurat digunakan untuk jual dan beli pada saham perusahaan sektor makanan dan minuman tahun 2013 s.d. 2015. Hasil penelitian ini memperkuat penelitian sebelumnya oleh Monika (2017) yang menyatakan bahwa indikator MACD akurat digunakan pada saham perusahaan sub sektor perbankan tahun 2015 s.d. 2016. Hasil ini juga mendukung penelitian dari Ghobadi (2014) yang menyatakan bahwa indikator RSI dapat memberikan return yang positif pada 8 komoditas tahun 2008 s.d. 2013.

Penelitian ini tidak mendukung penelitian dari Pramono et al. (2013) yang menyatakan indikator MACD dan RSI tidak menguntungkan. Penelitian Pramono menggunakan indikator MACD, SO, RSI, buy and hold di sektor perbankan indeks LQ45. Variabel yang diuji dengan indikator metode MACD menghasilkan dua return bernilai negatif, metode RSI hampir semua variabel menghasilkan return negatif, metode SO hanya menghasilkan satu return negatif, sedangkan metode buy and hold menghasilkan return positif. Penelitian ini juga berbeda dari Nor (2014) di bursa saham Australia yang menyatakan bahwa MACD umumnya berkinerja buruk, meskipun RSI menunjukkan beberapa potensi keuntungan. Perbedaan hasil penelitian ini dengan penelitian lainnya dapat disebabkan oleh objek, indikator maupun periode yang berbeda.

Berdasarkan hasil analisis sampel saham penelitian, indikator MACD dan RSI memiliki perbedaan jika dilihat berdasarkan kondisi pasar indeks JII. Kondisi pasar dapat juga dihitung dengan rumus cut off point untuk mengetahui keadaan indeks dari tahun ke tahun. Bullish berarti keadaan dimana pasar sedang dalam tren naik yang digambarkan sebagai optimisme investor, sebaliknya bearish merupakan keadaan dimana pasar dalam tren menurun dan investor dalam posisi pesimisme. Cut off point dihitung dengan metode arithmetic mean (simbol X bar). Menurut Tandelilin dalam Aditama (2016:37), arithmetic mean merupakan rumus untuk menghitung rata-rata yang dengan rumus:

$$
\overline{\mathrm{X}}=\frac{\Sigma \mathrm{X}}{n},
$$

$\Sigma \mathrm{X}=$ jumlah return selama suatu periode

$\mathrm{n}=$ jumlah periode
Tabel 2

Sinyal Indikator MACD dan RSI saat Kondisi Pasar Bullish dan Bearish

\begin{tabular}{cccccc}
\hline \multirow{2}{*}{ Tahun } & Indeks & Cut Off & \multirow{2}{*}{ Kondisi } & \multicolumn{2}{c}{ Jumlah Sinyal } \\
\cline { 5 - 6 } & Point & & & MACD & RSI \\
\hline 2016 & 694,13 & 712,81 & Bearish & 61 & 70 \\
2017 & 759,1 & 712,81 & Bullish & 40 & 55 \\
2018 & 685,2 & 712,81 & Bearish & 53 & 64 \\
Jumlah & & & & 154 & 189 \\
\hline
\end{tabular}

Pada saat kondisi pasar bearish, indikator MACD dan RSI memberikan sinyal yang lebih banyak dibandingkan saat pasar dalam kondisi bullish. Hasil ini menunjukkan bahwa harga saham bergerak lebih fluktuatif saat pasar dalam tren turun dan lebih stabil saat berada pada tren naik. Indikator MACD menghasilkan total 154 sinyal dan indikator RSI menghasilkan total 189 sinyal. Data ini menunjukkan bahwa indikator RSI lebih reaktif terhadap pergerakan harga saham dibandingkan dengan indikator MACD.

Perbandingan antara indikator MACD dengan RSI dapat dilihat dari berapa banyak sinyal dan return yang dihasilkan. Return dicari untuk mengetahui keuntungan atau kerugian serta untuk mengetahui indikator mana yang menghasilkan tingkat pengembalian yang lebih tinggi. Return pada penelitian ini dihitung seperti penelitian dari Aditama (2016) yang membandingkan antara return buy and hold dengan return dari analisis indikator Moving Average. Return saham yang digunakan adalah return buy and hold dan dibandingkan dengan return dari indikator yang disajikan pada tabel berikut:

Tabel 3

Perbandingan Return Buy and Hold dan Return Indikator

\begin{tabular}{lcccccc}
\hline & \multicolumn{2}{c}{ Harga } & \begin{tabular}{c} 
Return \\
Suy \\
\cline { 5 - 6 } Saham
\end{tabular} & \multicolumn{5}{c}{\begin{tabular}{c} 
Return Indikator \\
\cline { 5 - 6 }
\end{tabular}} & & & and & & \\
& 2016 & 2018 & Hold & MACD & RSI \\
\hline ADRO & 494 & 1215 & $146,0 \%$ & $161,6 \%$ & $217,2 \%$ \\
BSDE & 1750 & 1255 & $-28,3 \%$ & $80,6 \%$ & $74,7 \%$ \\
KLBF & 1280 & 1520 & $18,8 \%$ & $71,5 \%$ & $102,2 \%$ \\
PTPP & 3676 & 1805 & $-50,9 \%$ & $104,6 \%$ & $98,1 \%$ \\
SMRA & 1575 & 805 & $-48,9 \%$ & $94,9 \%$ & $172,1 \%$ \\
WIKA & 2478 & 1655 & $-33,2 \%$ & $116,7 \%$ & $131,1 \%$ \\
Rata-rata & & & $0,6 \%$ & $105 \%$ & $132,6 \%$ \\
\hline
\end{tabular}

Tabel 3 menunjukkan bahwa return buy and hold saham selama tahun 2016 s.d. 2018 lebih 
sedikit jika dibandingkan dengan return yang didapat investor dari indikator MACD dan RSI. Indikator RSI menghasilkan rata-rata return yang lebih tinggi dari indikator MACD (105) dan return buy and hold $(0,6 \%)$ yaitu sebesar $132,6 \%$. Tanpa analisis teknikal, investor akan mendapatkan return negatif dari saham BSDE, PTPP, SMRA dan WIKA. Hasil ini menunjukkan bahwa analisis teknikal khususnya indikator MACD dan RSI dapat memaksimalkan keuntungan investor dalam perdagangan saham.

\section{PENUTUP}

\section{Kesimpulan}

1. Hasil uji hipotesis $\mathrm{H}_{01}$ pada 6 sampel penelitian dengan kode: ADRO, BSDE, KLBF, PTPP, SMRA, dan WIKA selama periode penelitian, menunjukkan bahwa sinyal harga dari indikator MACD tidak berbeda dengan close price terdekat saham JII tahun 2016 s.d. 2018, sehingga sinyal beli dan sinyal jual yang dihasilkan oleh indikator MACD akurat dan dapat digunakan untuk mengambil keputusan berinvestasi di pasar modal.

2. Hasil uji hipotesis $\mathrm{H}_{02}$ menunjukkan bahwa sinyal harga dari indikator RSI tidak berbeda dengan close price terdekat saham JII tahun 2016 s.d. 2018, sehingga sinyal beli dan sinyal jual yang dihasilkan oleh indikator RSI akurat dan dapat digunakan untuk mengambil keputusan berinvestasi di pasar modal.

3. Hasil uji hipotesis $\mathrm{H}_{03}$ menunjukkan bahwa tidak terdapat perbedaan antara sinyal harga yang dihasilkan 2 indikator, sehingga pada obyek dan periode yang sama yaitu saham JII tahun 2016 s.d. 2018, indikator MACD dan RSI menghasilkan keputusan investasi (sinyal beli dan jual) yang sama secara statistik. Indikator MACD dan RSI sama-sama dapat memberikan jawaban waktu terbaik untuk membeli atau menjual suatu saham.

\section{DAFTAR PUSTAKA}

Aditama, Wimpi. (2016). Analisis Buy and Hold Strategy dan Moving Average pada saat Bullish dan Bearish di Pasar Modal (Studi pada Indeks IDX30 yang Terdaftar di Bursa Efek Indonesia Periode 2013-2015). Unpublished Essay, Universitas Lambung Mangkurat, Kalimantan Selatan.

Asthri, Dian Dwi Parama, Topowijono, \& Sulasmiyati, Sri. (2016). Analisis Teknikal dengan Indikator Moving Average Convergence Divergence untuk Menentukan
Sinyal Membeli dan Menjual dalam Perdagangan Saham. Jurnal Administrasi Bisnis (JAB), Vol. 33 No. 2, hal 41-48.

Chong, Terence Tai-Leung., Ng, Wing-Kam. \& Liew, Venus Khim-Sen. (2014). Revisiting the Performance of MACD and RSI Oscillators, Risk and Financial Management. ISSN 1911-8074, hal. 1-12.

Filbert, Ryan \& J1d. (2014). Bandarmology. Jakarta: PT Gramedia.

Ghobadi, Mohsen. (2014). Profitability of Technical Analysis Indicators to Earn Abnormal Returns in International Markets. Journsl of Economics, Finance and Accounting - (JEFA). ISSN: 2148-6697.

Hanafi, Mamduh M. (2016). Manajemen Keuangan. Yogyakarta: BPFE-Yogyakarta.

Kodrat, David Sukardi \& Indonanjaya, Kurniawan. (2010). Analisis Momentum pada Sahamsaham Perbankan di Bursa Efek Indonesia Pasca Krisis.

Monika, Noor Elma. (2017). Analisis Teknikal Menggunakan Indikator MACD untuk Membeli dan Menjual dalam Perdagangan Saham (Studi pada Perusahaan Sub Sektor Perbankan di BEI Periode Januari 2015 s.d. September 2016). Prosiding Seminar Nasional ASBIS 2017, ISSN:2541-6014, hal. 299-307.

Nor, Safwan Mohd. (2014). The Profitability of MACD and RSI trading rules in the Australian Stock Market. Investment Management and Financial Innovation, Vol. 11, Isuue 4, hal. 194-199.

Pandya, Hemal. (2013). Technical Analysis for Selected Companies of Indian IT Sector. International Journal of Advanced Research, Vol.1, Issue 4, hal. 430-446.

Pardiansyah, Elif. (2017). Investasi dalam Perspektif Ekonomi Islam: Pendekatan Teoritis dan Empiris. Jurnal Ekonomi Islam, Vol. 8, No.2, ISSN:2085-9325.

Pramono, Agung., Soenhadji, Imam Murtono., Mariani, Septi. \& Astuti, Ida. (2013). Analisis Teknikal Modern Menggunakan Metode MACD, RSI, SO dan Buy and Hold untuk Mengetahui Return Saham Optimal pada Sektor Perbankan LQ 45. Jurnal Proceeding PESAT (Psikologi, Ekonomi, Sastra, Arsitektur \& Teknik Sipil) Bandung, 8-9 Oktober 2013, Vol. 5 Oktober, ISSN: 1858-2559.

Putri, F.K., Bramanti, W.G., \& Hakim, M.S. (2017). Pengaruh Faktor Kepribadian terhadap Toleransi Risiko Keputusan 
Investasi Saham. Jurnal Teknik ITS, Vol.6, No.1, ISSN: 2337-3539.

Raditya, Tri Murda Agus., Tarno, \& Wuryandari, Triastuti. (2013). Penentuan Tren Arah Pergerakan Harga Saham dengan Menggunakan Moving Average Convergence Divergence. Jurnal Gaussian, Vol.2, No.3, Th.2013, hal. 249-258.

Wira, Desmond. (2014). Analisis Teknikal untuk Profit Maksimal. (Edisi 2). Jakarta: Exceed.

Yustati, Herlina. (2017). Efektivitas Pemanfaatan Sistem Online Trading Syariah dalam Menigkatkan Investor Saham di Pasar Modal Syariah. Journal of Islmaic Economics, Finance and Banking. Vol.1 No.2, November 2017, hal 107-122.

\section{Profil Penulis}

1. Noor Elma Monika S.M., M.M., Magister Manajemen, Fakultas Ekonomi dan Bisnis Universitas Lambung Mangkurat. Jl. Brigjen H. Hasan Basri, Pangeran, Kec. Banjarmasin Utara, Kota Banjarmasin, Kalimantan Selatan 70123.

Email: elmamonika@gmail.com

2. Dr. Meina Wulansari Yusniar, S.E., M.Si., Magister Manajemen, Fakultas Ekonomi dan Bisnis Universitas Lambung Mangkurat. Jl. Brigjen H. Hasan Basri, Pangeran, Kec. Banjarmasin Utara, Kota Banjarmasin, Kalimantan Selatan - 70123.

Email: $\underline{\text { meina_unlam@yahoo.co.id }}$ 